\title{
ISOLATION, PRIMARY STRUCTURE AND SYNTHESIS OF NEOMYOSUPPRESSIN, A MYOINHIBITING NEUROPEPTIDE FROM THE GREY FLESHFLY, NEOBELLIERIA BULLATA
}

\author{
Adrien Fónagy, ${ }^{*}$ Liliane Schoofs, $₫$ Paul Proost $\S$ Jo Van Damme,, Hilde Bueds $\ddagger$ \\ and ARNold De Loof $\ddagger$
}

*Plant Protection Institute of the Hungarian Academy of Sciences, Budapest II, P.O.B. 102, H-1525, Hungary; †Zoological Institute, Katholieke Universiteit Leuven, Naamsestraat 59, B-3000 Leuven, Belgium; and $\S$ Rega Institute, Katholieke Universiteit Leuven, Minderbroedersstraat 10, B-3000 Leuven, Belgium

\section{(Received 8 October 1991)}

\begin{abstract}
An amidated decapeptide, showing strong inhibitory activity of spontaneous visceral muscle movement was isolated, from head extracts of 42 thousand fleshflies, Neobellieria bullata (Diptera, Sarcophagidae).

2. Amino acid sequencing and verification by peptide synthesis revealed the following primary structure: Thr-Asp-Val-Asp-His-Val-Phe-Leu-Arg-PheNH ${ }_{2}$.

3. The novel peptide was termed neomyosuppressin or Neb-MS.

4. During the process of consecutive high performance liquid chromatography (HPLC) purifications the biological activity of the samples was monitored using heterologous bioassay system.

5. The threshold level of synthetic Neb-MS was found to be $8.6 \pm 0.5 \times 10^{-11} \mathrm{M}$ on the Leucophaea hindgut and $3.4 \pm 0.5 \times 10^{-10} \mathrm{M}$ on the Locusta oviduct bioassay, respectively.
\end{abstract}

\section{INTRODUCTION}

In recent years the improvement of chromatographical, immunological and molecular biological techniques made it possible to isolate and characterize a growing number of insect neuropeptides from different insect sources (for reviews see Holman et al., 1990; De Loof and Schoofs, 1990). In many cases the bioactive peptides show significant homology with respective vertebrate (and/or invertebrate) neuropeptides (De Loof and Schoofs, 1990).

Following the pioneering discovery of proctolin in Periplaneta americana (Starratt and Brown, 1975), several other visceral muscle stimulating peptides have been isolated such as the leucokinins (I-VIII), leucopyrokinin, leucosulfakinins (I-II) from Leucophaea maderae (for references see Holman et al., 1990) or locustamyotropins (I-IV), locustatachykins (I-IV), locustasulfakinin, locustapyrokinin and locustakinin (Schoofs et al., 1990a-e; 1991a-c) from Locusta migratoria. Locustatachykins exhibit sequence homology to peptides of the vertebrate tachykinin family (Schoofs et al., 1990c-d). Leucosulfakinins (Nachman et al., 1986a,b), locustasulfakinin (Schoofs et al., 1990e) and neosulfakinins from Neobellieria bullata (Fónagy et al., 1992) exhibit structural identities with vertebrate gastrointestinal peptides. All these studies show the rapid improvement in insect neurohormone research and provide possibilities for the study of the complex functions of these substances.

FMRFamide (Phe-Met-Arg-PheNH ${ }_{2}$ ), the first member of an other intensively growing interphyletic family was originally isolated from the clam Macrocallisticia nimbosa (Price and Greenberg, 1977) as a cardioexcitatory neuropeptide. This family (and its leucine analogue FLRFamides) shares structural homologies (primarily at the carboxy-terminal end) with peptides and peptide families originating from other invertebrate and vertebrate phyla (Greenberg et al., 1988). The FM(L)RFamide family seems to be a complex group of peptides; for example the insect sulfakinins (Nachman et al., 1986a-b; Schoofs et al., 1990e, Fónagy et al., 1992), leucomyosuppressin, (Holman et al., 1986b) or the SchistoFLRFamide (Robb et al., 1989) all belong to the same group.

The first inhibitory factor, the leucomyosuppressin was purified from Leucophaea maderae (Holman et al., 1986b), followed by SchistoFLRFamide from Schistocerca gregaria (Robb et al., 1989) and locustamyoinhibiting peptide from $L$. migratoria (Schoofs et al., 1991d).

In the present paper we report the isolation, amino acid sequence determination, synthesis and biological activity of a new insect myosuppressin peptide. According to the suggested insect peptide nomenclature (Raina and Gäde, 1988) it was termed neomyosuppressin or Neb-MS and it was isolated from head extracts of the fleshfly, Neobellieria bullata (Diptera; Sarcophagidae). This peptide has its carboxy-terminal in common with other vertebrate and invertebrate peptides of the FM(L)RFamide family.

\section{Insects}

\section{MATERIALS AND METHODS}

Neobellieria bullata (Diptera, Sarcophagidae) was reared under laboratory conditions in mass culture as described by 
Huybrechts and De Loof (1981). The colonization of Leucophaea maderae was done as reported by Cook and Holman (1978). Locusta migratoria $\mathbf{R}$ and $\mathrm{F}$ were reared according to Ashby (1972).

\section{Tissue extraction}

The heads of 42,000 7-10 days old male and female flies were cut off during a period of two months. The heads were collected, homogenized and extracted in a methanol/water/ acetic acid $(90: 9: 1)$ mixture. The extraction procedure has been described elsewhere (Fónagy et al., 1992). The subsequent prepurification on Sep-pak cartridges was performed according to Holman et al. (1986a).

\section{HPLC separation and purification}

HPLC purification was performed on an LKB Liquid Chromatograph equipped with one pump (LKB 2150), a controller (LKB 2152), a variable wavelength monitor (LKB 2151) and mixer driver (LKB 1130). Processing of crude extracts required the use of four different types of columns, consecutively.

Initially, fractionation of the prepurified extract was performed on Waters- $\mu$-Bondapak Phenyl $(30 \mathrm{~cm} \times 4.6 \mathrm{~mm})$ column under the following operating conditions: $100 \%$ solvent $A$ for $8 \mathrm{~min}$, then a linear gradient to $100 \%$ solvent B for $120 \mathrm{~min}$; solvent A, $0.1 \%$ trifluoroacetic acid (TFA) in water; Solvent B, $50 \%$ acetonitrile in $0.1 \%$ aqueous TFA. Flow rate was $1.5 \mathrm{ml} / \mathrm{min}$, detector was set at 2.56 absorbance range at $214 \mathrm{~nm}$. Fractions were collected arbitrary every $2 \mathrm{~min}$ with automatic fraction collector (Bio-Rad $2110)$.

In the second step, separation of the biologically active, pooled samples was carried out on Supelcosil LC-1 $(25 \mathrm{~cm} \times 4.6 \mathrm{~mm})$ column. Conditions were as follows: $100 \%$ solvent $A$ for $6 \mathrm{~min}$, then linear gradient to $100 \%$ solvent $B$ for $80 \mathrm{~min}$; solvent $A$ and $B$ and other conditions were as during primary fractionation.

Thirdly, further purification of pooled samples was done on Supelcosil LC $-8(15 \mathrm{~cm} \times 4.6 \mathrm{~mm})$ column as follows: $100 \%$ solvent $A$ for $8 \mathrm{~min}$ then linear gradient to $100 \%$ solvent B for $120 \mathrm{~min}$; Solvent A and B were same as at primary fractionation. Flow rate was $1.5 \mathrm{ml} / \mathrm{min}$ and detector was set at 1.28 absorbance range at $214 \mathrm{~nm}$. Individual peaks were collected manually.

Final purification of biologically active fractions was carried out on Waters Protein Pak $125(30 \mathrm{~cm} \times 7.8 \mathrm{~mm})$ column. Operating conditions: $100 \%$ solvent $\mathbf{A}$ for $8 \mathrm{~min}$ then linear gradient to $100 \%$ solvent B for $80 \mathrm{~min}$; solvent A was $95 \%$ acetonitrile made to $0.01 \%$ TFA; solvent B was $50 \%$ acetonitrile in $0.01 \%$ aqueous TFA. Flow rate was $1.5 \mathrm{ml} / \mathrm{min}$ and detector was at 0.32 or 0.16 absorbance range at $214 \mathrm{~nm}$. Peaks were collected manually.

Following final purification, the biologically active fraction was rerun on the Protein Pak column under similar conditions as described above to ensure purity.

\section{Bioassays}

For the monitoring of biological (myogenic) activity heterologous in vitro bioassays were performed. The preparation of the Leucophaea hindgut bioassay has been described previously (Cook and Holman, 1978). Dissection of Locusta ovaries and preparation of the oviduct and bioassays were carried out in Locusta saline as reported previously (Paemen et al., 1990).

\section{Enzymatic analysis}

A dried aliquot containing approximately 1000 head equivalents of the purified peptide was subjected to an aminopeptidase digestion test, before amino acid sequencing. The peptide residue was dissolved in $150 \mu$ l insect ringer solution. To $50 \mu 1$ of the immobilized amidopeptidase $M$ (Pierce Chemical Company) containing $0.5 \mathrm{unit} / \mathrm{ml}, 200 \mu \mathrm{l}$ insect Ringer was added which was centrifuged, resuspended and decanted twice. The dissolved peptide was added to the aminopeptidase gel suspension. Following the 2 hours incubation at $37^{\circ} \mathrm{C}$ the gel was removed from the suspension by centrifugation and the supernatant was again bioassayed. A sample of peptide without aminopeptidase was also incubated as a control. In addition, 100 pmole of a blocked synthetic peptide, locustapyrokinin was (Schoofs $e t$ al., 1991d) incubated with aminopeptidase as a control for the enzymatic reaction. The disappearance of biological activity indicated that the $N$-terminal of the purified peptide was not blocked.

\section{Sequence analysis}

An aliquot of the purified peptide (approximately one fourth) was degraded sequentially using Edman degradation and the amino acids were converted to the phenylthiodantoin (PTH) derivatives with the Applied Biosystems modes 477A pulsed liquid phase protein sequencer. PTH amino acids were identified with the online mode 120A PTH analyser according to the instructions supplied by the manufacturer. The natural peptide was quantified according to the concentrations measured during sequencing.

\section{Peptide synthesis}

The chemical synthesis was carried out on solid phase with a Biolynx ${ }^{(\mathrm{TM})} 4170$ peptide synthesizer (Pharmacia LKB) using the Fmoc polyamide chemistry (9-fluorenylmethoxycarbonyl amino protecting groups) as described previously (Schoofs et al., 1991d). Briefly, the ultrasyn c solid phase support with a mild acid labile handle designed specially for the synthesis of peptide amides by the Fmoc polyamide continuous flow method was used to yield the $C$-terminal amide of the presumed sequence. The following amino acid derivatives were used when side chain protection was mandated: Fmoc-L-arginine(Mtr)DHBT, Fmoc-L-threonine(But)DHBT. Cleavage of the peptide and removal of the side chain protecting groups was achieved in one step by treatment with $95 \%$ TFA with $5 \%$ anisol as scavenger.

The synthetic peptide was prepurified on Sep-pak cartridges. Further purification was carried out on a SuperPac $S$ column (Pharmacia) $(0.4 \times 25 \mathrm{~cm})$. Solvent A: $0.1 \%$ TFA in water; solvent $B: 50 \%$ acetonitrile in water made to $0.1 \%$ TFA. Initial conditions $100 \%$ solvent A for $8 \mathrm{~min}$, then linear gradient to $100 \%$ solvent $B$ over $80 \mathrm{~min}$. Flow rate $1.5 \mathrm{ml} / \mathrm{min}$. Detector range 2.5 absorbance units full scale at $214 \mathrm{~nm}$. The collected peak was analyzed by amino acid analysis. Aliquots of the purified peptide were run on the four different columns that were used for the isolation of the natural peptide to compare retention times.

\section{Amino acid analysis}

The amino acid contents of the purified synthetic peptide was determined using the DABS (dimethylaminoazobenzene sulfonyl chloride pre-column derivatization method) on a Beckman System Gold HPLC. Prior to derivatization, samples were hydrolysed with aqueous $6 \mathrm{~N} \mathrm{HCl}$ at $120^{\circ} \mathrm{C}$ for $18 \mathrm{~h}$. Samples were derivatized and HPLC analysed according to instructions supplied by the manufacturer. The amino acid analysis of the synthetic peptide also allowed it to be quantified for use in the bioassay system.

\section{Threshold concentrations}

Threshold concentrations of synthetic peptide were determined by adding known quantities of peptides into the bioassay chamber containing the isolated Leucophaea hindgut or the Locusta oviduct. The threshold concentrations were determined as the concentration required to evoke an observable change (i.e. in frequency, amplitude and/or tonus) within 30 seconds.

\section{RESULTS}

Following the initial HPLC analysis on the Waters- $\mu$-Bondapak Phenyl column the presence of 


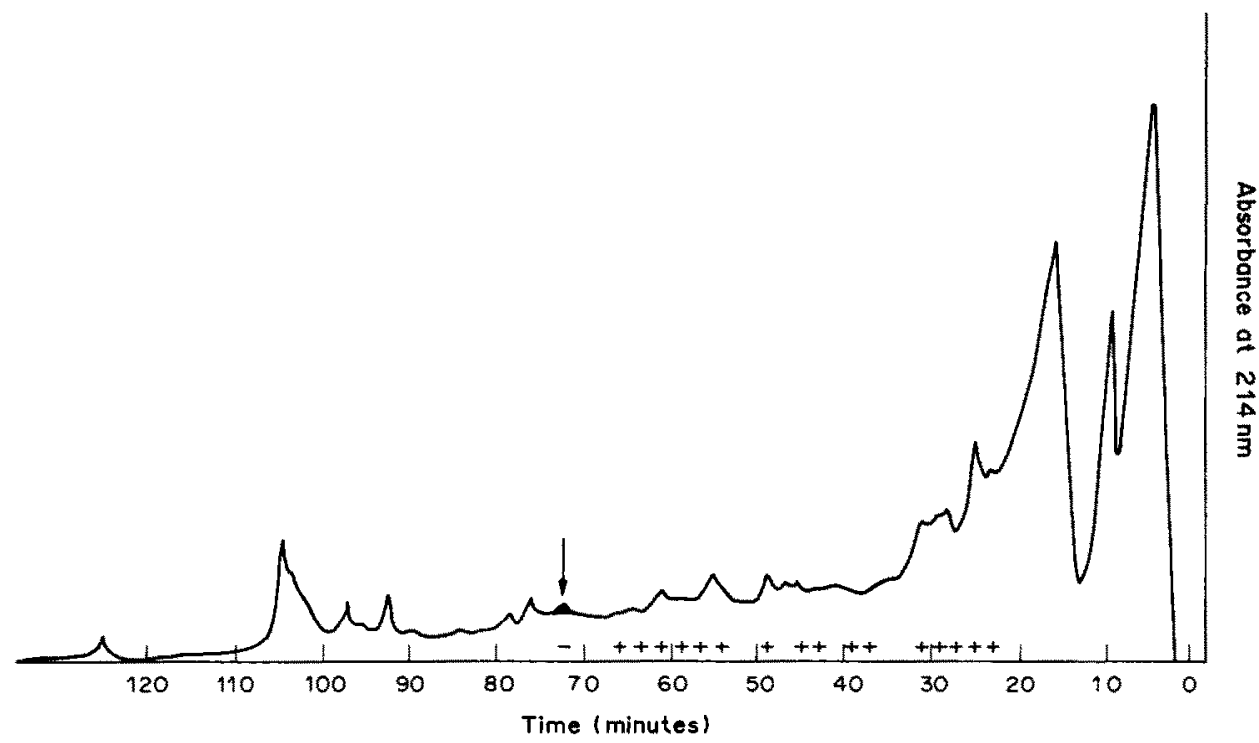

Fig. 1. HPLC fractionation on Waters- $\mu$-Bondapack-phenyl column of an extract, containing 500 Neobellieria bullata head equivalents. Fractions containing inhibitory ( - ) or stimulating $(+)$ activity on Leucophaea hindgut and/or Locusta ovary bioassay are shown. Inhibitory fraction on Leucophaea hindgut and Locusta oviduct eluting at $72-74 \mathrm{~min}$ is indicated.

16 activating and 1 inhibiting fraction was recorded, where the activity was observed either on the Leucophaea hindgut or on the Locusta oviduct or in both assay systems (Fig. 1) (Fónagy et al., 1990, Fónagy et al., 1992). The respective, biologically active samples were pooled and retained. A total of 84 sufficiently reproducible- HPLC runs, each containing approximately 500 head equivalents, were required to process the Speed-Vac concentrated and dried Sep-pak extracts through the $\mu$-Bondapak Phenyl column. In the subsequent process, the relatively small amounts of remaining material allowed us to conduct further purification steps with one or two passes through the respective columns.

In this paper we describe the further purification of the inhibiting fraction which eluted at $72-74 \mathrm{~min}$ during the initial fractionation (Fig. 1). This fraction inhibited both gut and oviduct spontaneous motility.

Following pooling, Sep-pak purification and Speed-Vac concentration the samples were subjected to the second purification step. Fractions containing biological (inhibiting) activity eluted at $18-20$ and 20-22 min on the $L C-1$ column, respectively (Fig. 2).

The separately pooled samples of the two active fraction were subjected to the next purification step, the $L C-8$ column separation, where both samples (i.e $18-20$ and $20-22 \mathrm{~min}$ fractions of the $L C-1$ purification) partially showed the presence of similar materials indicating a possible overlap at respective areas (Fig. 3). From the third purification step performed on $L C-8$ column, however, only one inhibiting peptide fraction (in two runs) was obtained

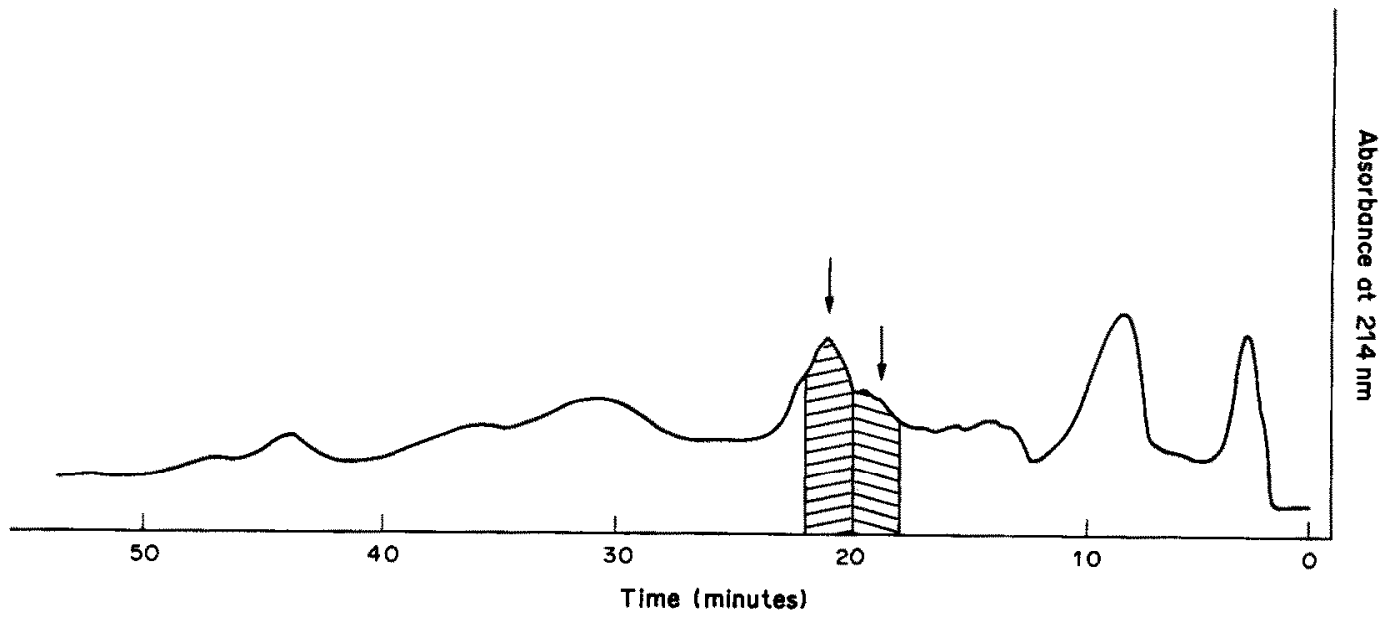

Fig. 2. Fractionation on Supelcosil LC.1 column of area indicated on Fig. 1. Myoinhibiting activity eluted in 2 fractions as indicated, at $18-20$ and $20-22 \mathrm{~min}$, respectively. 


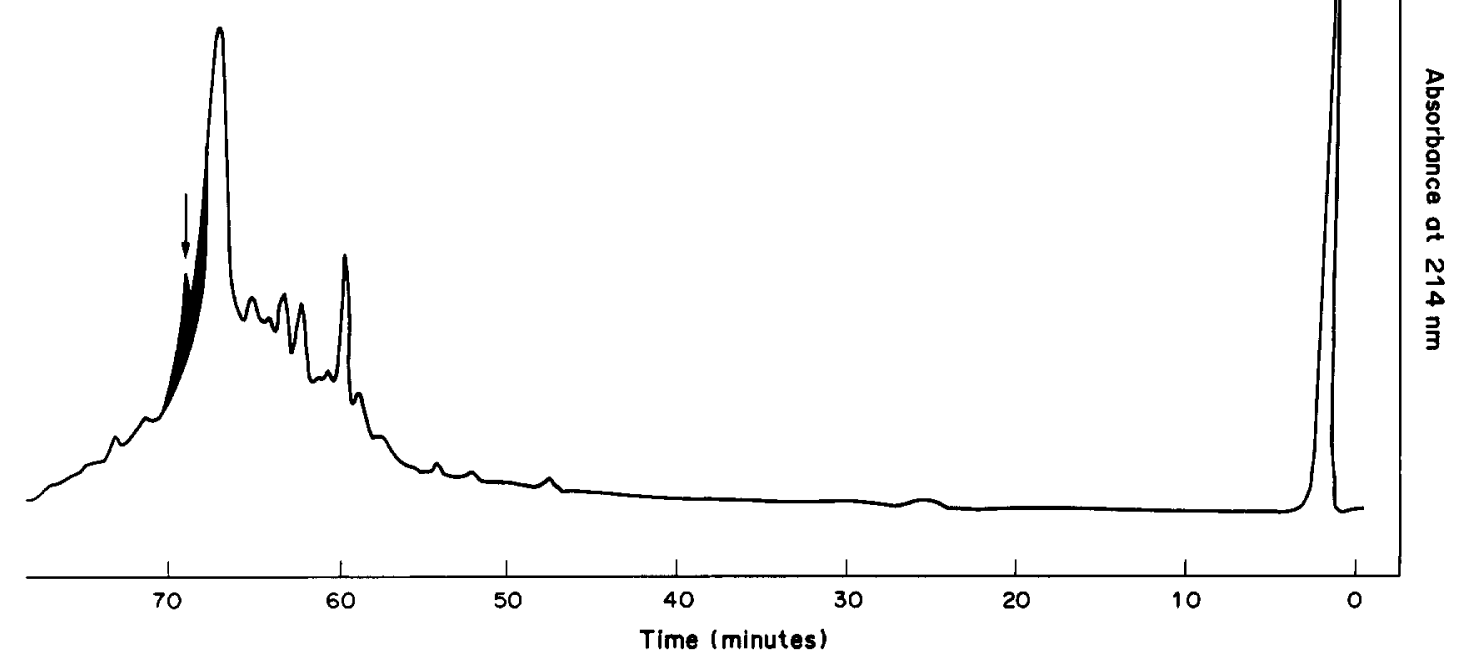

Fig. 3. Fractionation on Supelcosil LC -8 column of area eluting at 18-20 and 20-22 min on Supelcosil $L C-1$ column. In both (identical) runs an active fraction at $69 \mathrm{~min}$ is indicated.

eluting at $69 \mathrm{~min}$. When the pooled peaks eluting at 69 min on the $L C \cdot 8$ column (Fig. 3) were purified on Protein Pak column the presence of two inhibiting peptide fractions were revealed eluting at 36 and $38 \mathrm{~min}$, respectively (Fig. 4). An aliquot of the peak eluting at $36 \mathrm{~min}$ was subjected to enzymatic analysis, then to amino acid sequencing. The other fraction is retained and further studies will be performed later.

The enzymatic analysis test indicated that the $N$-terminal of the newly isolated peptide was most likely not blocked so it was directly subjected to amino acid sequencing. One-fourth of the total amount

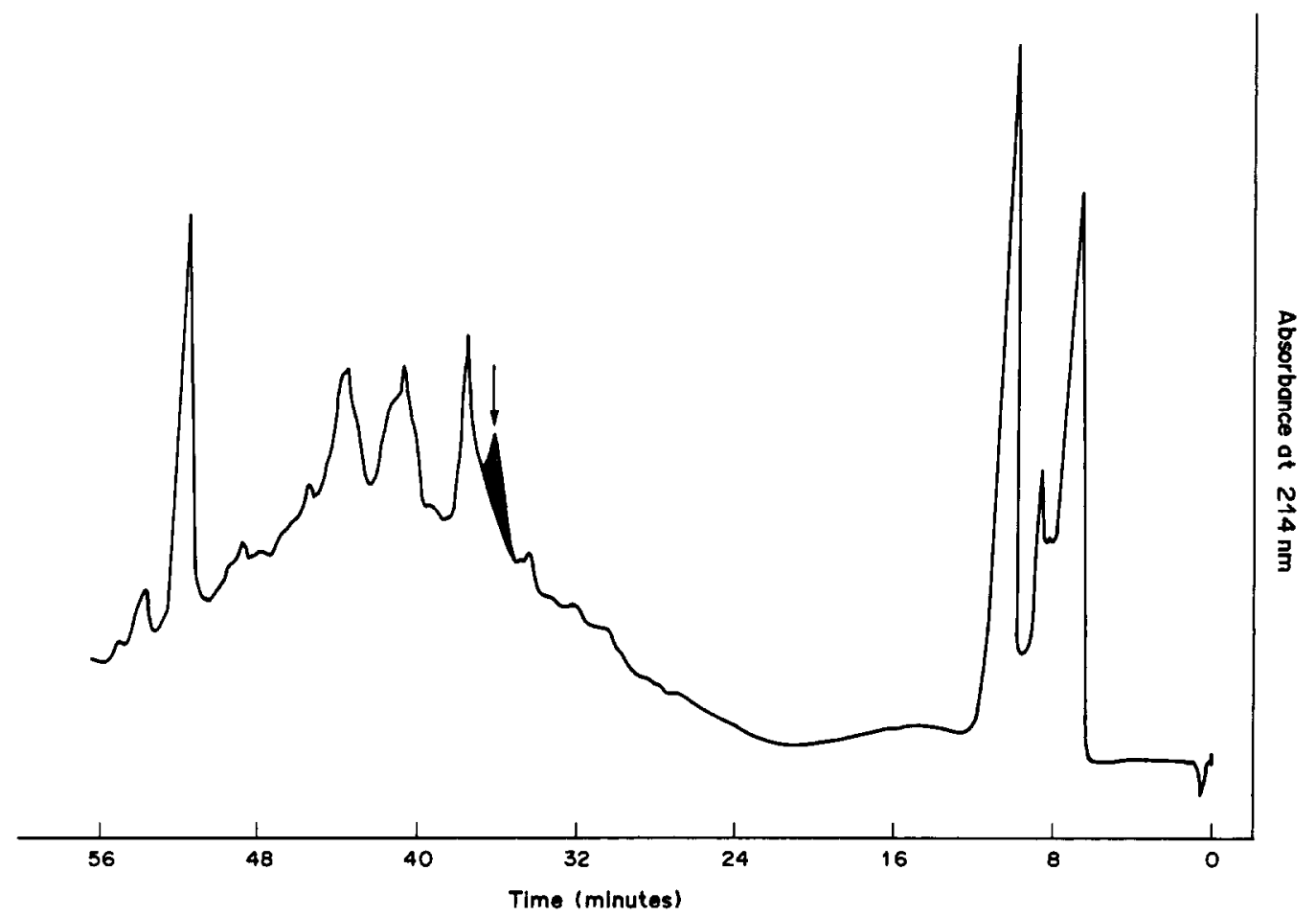

Fig. 4. Fractionation on Waters Protein Pak column of pooled samples indicated on Fig. 3. ( $L C-8$ column) eluting at 36 and $38 \mathrm{~min}$. The purified peptide eluting at 36 min (indicated) is termed neomyosuppressin. 

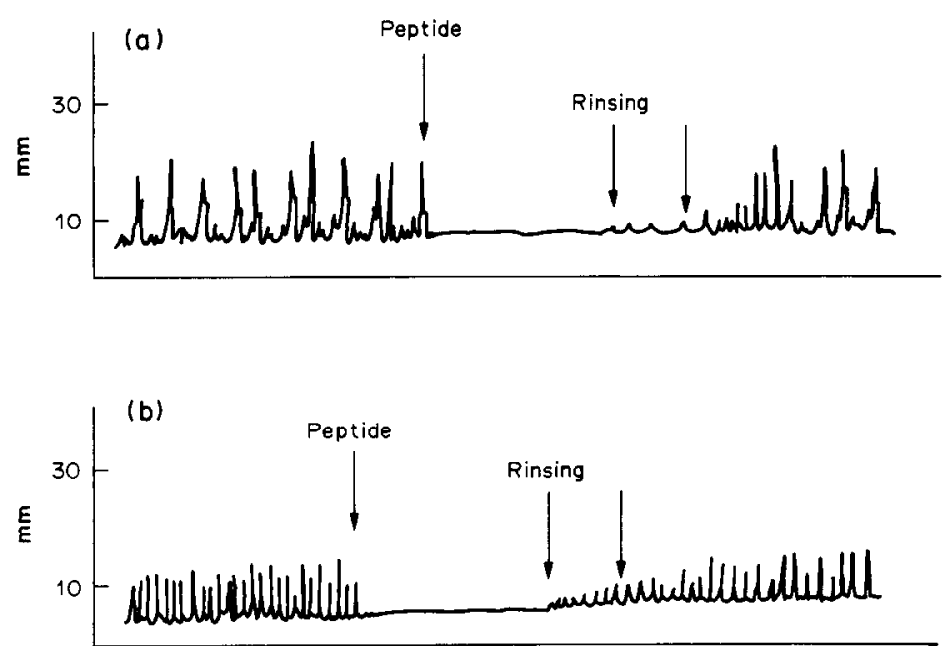

Fig. 5. Bioactivity of the synthetic neomyosuppressin on the spontaneous contraction of the isolated Leucophaea hindgut (a) and Locusta oviduct (b). (a) Administration of approximately $8 \times 10^{-11}$ of Neb-MS inhibits spontaneous contraction of hindgut. (b) Administration of approximately $3 \times 10^{-10}$ of Neb-MS inhibits spontaneous contraction of oviduct. After rinsing with pure saline the base contraction pattern returns.

was used for amino acid sequencing. The primary sequence of this peptide was determined to be: ThrAsp-Val-Asp-His-Val-Phe-Leu-Arg-Phe (MW: 1138).

As it was calculated from the amino acid sequence analysis an amount of 240 pmole of neomyosuppressin, Neb-MS was isolated (not taking into account the losses during purification). The threshold level of the natural product was $5.2 \pm 0.7 \times 10^{-11} \mathrm{M}$ on the Leucophaea hindgut and $3 \pm 0.6 \times 10^{-10} \mathrm{M}$ on the Locusta oviduct bioassay. The threshold level of the synthetic peptide (amidated form) could be, however, much more precisely determined: $8.6 \pm 0.5 \times 10^{-11} \mathrm{M}$ concentration resulted in complete gut motility inhibition, whereas $3.4 \pm 0.5 \times 10^{-10} \mathrm{M}$ caused oviduct spontaneous movement inhibition. Both natural and synthetic peptides have similar bioactivity profile (Fig. 5).

The response of the isolated organs to Neb-MS was dose dependent and reversible. With increasing concentrations a drop in tonus was also observed. Following removal of the peptide from the chamber the frequency (and tonus) recovered within 3-5 min, the amplitude, however, remained depressed for longer time.

\section{DISCUSSION}

We have isolated a new member of insect myosuppressins and/or FM(L)RFamide peptide based on consecutive HPLC purification steps. The activity of the biological samples were monitored on heterologous bioassay systems. The employment of such heterologous bioassay screening methods has been successfully proved in a number of recent similar insect neuropeptide isolation, purification works (Schoofs et al., 1990a-e; 1991a-d).

The Neb-MS is the first inhibitory peptide isolated from Diptera. Based on previous reports (Holman et al., 1986b; Robb et al., 1989) and our present result we may conclude, that a separate insect (FLRFamide) myosuppressin subgroup exists, the respect- ive peptides originating from different insect groups seem to show a very close relationship to some other insect inhibitory peptides (Table 1). The members of this subgroup have, however, a strikingly different structure from the recently isolated locustamyoinhibiting (Lom-MIP) peptide (Schoofs et al., 1991d).

The first member of this group was isolated from L. maderae (Holman et al., 1986b) and this Lem-MS has a pGlu residue at the $N$-terminal end. The next identified member, the SchistoFLRFamide (Scg-MS) is also a decapeptide differing from the previous peptide with only one amino acid, the Pro being the $N$-terminal amino acid (Robb et al., 1989). Both the $N$-terminal pyroglutamate or the occurrence of proline may be alternative ways of protecting peptides from aminopeptidase cleavage during proteolytic maturation (Metlein, 1988). Interestingly, recently an other inhibitory decapeptide was isolated from Locusta migratoria from the brain-corpora cardiaca/ corpora allata-subesophageal ganglion complexes (Lom-MS) (Schoofs, unpublished results) which is identical to Scg-MS. This peptide has also the characteristic feature to totally inhibit spontaneous contraction of isolated Leucophaea hindgut and Locusta oviduct preparations.

As to the modes of action of these myosuppressins different conclusions have been drawn. Besides the primarily described effect of Lem-MS (i.e. inhibition of spontaneous contractile activity of isolated Leucophaea hindgut), it was recently shown that it attenuated evoked transmitter release from the presynaptic membrane of excitatory motor neurons of Tenebrio molitor skeletal muscles (Yamamoto et al., 1988). On the other hand, Robb et al. (1989) reported the

Table 1. Comparison of different insect myosuppressin structures Lem-MS pGlu-Asp-Val-Asp-His-Val-Phe-Leu-Arg-PheNH Scg-MS Pro-Asp-Val-Asp-His-Val-Phe-Leu-Arg-PheNH Neb-MS Thr-Asp-Val-Asp-His-Val-Phe-Leu-Arg-PheNH 
suppression of spontaneous contractions of the heart by SchistoFLRFamide, but they also described the potent potentiating effects on the extensor-tibiae muscle and long term potentiation effect on the amplitude of spontaneous heart contractions of $S$. gregaria. Due to the above diverse effects the name was proposed after some aspects of its structure rather then after its known functions (Robb et al., 1989). As for the similar peptide isolated from L. migratoria, or for Neb-MS, however, only hindgut and ovarian movement inhibitory effects have been investigated. These findings may further underline the complexity of possible actions of respective peptides in different insect and/or assay systems.

The fact that these myosuppressins may as well be members of the FM(L)RFamide family should not be neglected either and we might as well group this new peptide into this family based on its structure. The original FMRFamide, a cardioexcitatory peptide was isolated from a clam (Price and Greenberg, 1977). Since then a family of related peptides has been discovered in molluscs (Price, 1986); other vertebrate and invertebrate peptide families with similar $C$ terminal regions have also been identified (Greenberg et al., 1988). By using antibodies directed against the $C$-terminal end of the peptide, further pieces of evidences exist for FM(L)RFamide related neuropeptides present in nervous and gastrointestinal systems of invertebrates and vertebrates (for review see De Loof and Schoofs, 1990). Moreover, the hindgut stimulating insect sulfakinins (Nachman et al., 1986a, b, Schoofs et al.,1990e, Fónagy et al., 1992) also have the characteristic MRF sequence at their $C$-termini and are known to show far-reaching homology to human gastrin, cholecystokinins and caerulin, therefore they can be regarded as molecular links toward FM(L)RF and gastrointestinal hormones (Nachman et al., 1988). In the future, however, many more studies are required to elucidate what may be the functional significance of so many apparently different, but on the other hand (structurally) somewhat similar neuropeptides, for example in the FM(L)RFamide peptide family.

In summary, we have isolated a new insect neuropeptide bearing an FLRFamide $C$-terminal. As for the nomenclature and grouping, however, we propose the name Neb-MS due to its primary, first reported biological function (for reference see Raina and Gäde, 1988). Moreover, probably the specialized inhibitory effect of these peptides may be attributed to the consequently present

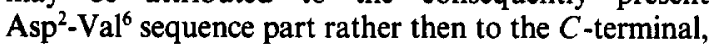
but which portion of these peptides in particular is essential for its biological effect is not yet clear. We believe that more attention (based on different structure-activity relationship studies) should be payed in the future to this regulatory peptide group.

Acknowledgements - The Hungarian "Soros Foundation" and the Catholic University of Leuven for providing a research grant for Dr A. Fónagy is specially acknowledged. We thank Dr S. Matsumoto for critical reading of the manuscript and Ms Kristine Pycke for technical assistance with peptide synthesis. This project was supported by the I.W.O.N.L. and N.F.W.O. of Belgium.

\section{REFERENCES}

Ashby G. J. (1972) Locusts. In The UFAW handbook on the care and management of laboratory animals (Edited by UFAW), pp. 582-587. Churchill Livingstone, Edinburgh London.

Cook B. J. and Holman G. M. (1978) Comparative pharmacological properties of muscle functions in the foregut and the hindgut of the cockroach Leucophaea maderae. Comp. Biochem. Physiol. 61C, 291-295.

De Loof A. and Schoofs L. (1990) Homologies between the amino acid sequences of some vertebrate peptide hormones and peptides isolated from invertebrate sources. Comp. Biochem. Physiol. 95B, No. 2, 459-468.

Fónagy A. Schoofs L., Van Damme J., Billiau A. and De Loof A. (1990) The isolation and purification of novel myotropic peptides from the fleshfly, Neobellieria bullata (Diptera, Sarcophagidae). In Abs. Vol. 15th Conf. of European Comparative Endocrinologists, pp. 42. Leuven, Belgium.

Fónagy A., Schoofs L., Proost P., Van Damme J. and De Loof A. (1992) Isolation and primary structure of two sulfakinin-like peptides from the fleshfly, Neobellieria bullata. (submitted). Comp. Biochem. Physiol.

Greenberg M. J., Payza K., Nachman R. J., Holman G. M. and Price D. A. (1988) Relationships between the FMRFamide-related peptides and other peptide families. Peptides. 9, $125-135$.

Holman G. M., Cook B. J. and Nachman R. J. (1986a) Primary structure and synthesis of two additional neuropeptides from Leucophaea maderae: members of a new family of cephalomyotropins. Comp. Biochem. Physiol. 84C, 271-276.

Holman G. M., Cook B. J. and Nachman R. J. (1986b) Isolation, primary structure and synthesis of leucomyosuppressin, an insect neuropeptide that inhibits the spontaneous contractions of the cockroach hindgut. Comp. Biochem. Physiol. 85C, 329-333.

Holman G. M., Nachman R. J. and Wright M. S. (1990) Insect neuropeptides. Ann. Rev. Entomol. 35, 201-217.

Huybrechts R. and De Loof A. (1981) Effect of ecdysterone on vitellogenine concentration in haemolymph of male and female Sarcophaga. Int. J. Invert. Reprod. 3, 157-168.

Metlein R. (1988) Proline residues in the maturation and degradation of peptide hormones and neuropeptides. FEBS Lett. 234, 251-256.

Nachman R. J., Holman G. M., Cook B. J., Haddon W. F. and Ling N. (1986a) Leucosulfakinin-II, a blocked sulfated insect neuropeptide with homology to cholecystokinin and gastrin. Biochem. Biophys. Res. Commun. 140, 357-364.

Nachman R. J., Holman G. M., Haddon W. F. and Ling N. (1986b) Leucosulfakinin, a sulfated insect neuropeptide with homology to gastrin and cholecystokinin. Science 234, 71-73.

Paeman L., Schoofs L. and De Loof A. (1990) Presence of myotropic peptides in the male accessory reproductive glands of Locusta migratoria. J. Insect Physiol. 36, 861-867.

Price D. A. (1986) Evolution of a molluscan cardioregulatory neuropeptide. Am. Zool. 26, 1007-1015.

Price D. A. and Greenberg M. J. (1977) Structure of molluscan cardioexcitatory neuropeptide. Science 189, 670-671.

Raina A. K. and Gäde G. (1988) Insect peptide nomenclature. Insect Biochem. 18, 785-787.

Schoofs L., Holman G. M., Hayes T. K., Tips A., Nachman R. J., Vandesande F. and De Loof A. (1990a) Isolation, identification and synthesis of locustamyotropin (LomMT), a novel biologically active insect neuropeptide. Peptides 11, No. 3, 427-433.

Schoofs L., Holman G. M., Hayes T. K., Nachman R. J. and De Loof A. (1990b) Isolation, identification and 
synthesis of locustamyotropin II, an additional neuropeptide of Locusta migratoria: Member of the cephalomyotropic peptide family. Insect Biochem. 20, 479-484.

Schoofs L., Holman G. M., Hayes T. K., Nachman R. J. and De Loof A. (1990c) Locustatachykinin I and II, two novel insect neuropeptides with homology to peptides of the vertebrate tachykinin family. FEBS Letl. 261, No. 2, 397-401.

Schoofs L., Holman G. M., Hayes T. K., Kochansky J., Nachman R. J. and De Loof A. (1990d) Locustatachykinin III and IV: two additional insect neuropeptides with homology to peptides of the vertebrate tachykinin family. Regulatory Peptides 31, 199-212.

Schoofs L., Holman G. L., Hayes T. K., Nachman R. J. and De Loof A. (1990e) Isolation and identification of sulfakinin-like peptide with sequence homology to vertebrate gastrin and cholecystokinin from the brain of Locusta migratoria. In Chromatography and Isolation of Insect Hormones and Pheromones (Edited by McCaffery A. and Wilson I.) pp. 231-241. Plenum Press, New York

Schoofs L., Holman G. M. Hayes T. K., Nachman R. J., Kochansky J. P. and De Loof A. (1991a) Isolation, identification and synthesis of locustamyotropin III and IV, two additional neuropeptides of Locusta migratora: members of the locustamyotropin peptide family. Insect Biochem. (submitted).
Schoofs L., Holman G. M., Hayes T. K., Nachman R. J. and De Loof A. (1991b) Isolation and identification of locustapyrokinin, a myotropic peptide from Locusta migratoria. Gen. Comp. Endocr. 81, 97-104.

Schoofs L., Holman G. M., Proost P., Van Damme J., Hayes T. K. and De Loof A. (1991c) Locustakinin, a novel myotropic peptide from the Locusta migratoria, isolation, primary structure and synthesis. Regulatory Peptides (submitted).

Schoofs L., Holman G. M., Hayes T. K., Nachman R. J. and De Loof A. (1991d) Isolation, identification and synthesis of Locustamyoinhibiting peptide (Lom-Mip), a novel biologically active neuropeptide from Locusta migratoria. Regulatory peptides (in press).

Starratt A. N. and Brown B. E. (1975) Structure of pentapeptide proctolin, a proposed neurotransmitter in insects. Life Sci. 17, 1253-1256.

Robb S., Packman L. C. and Evans P. D. (1989) Isolation, primary structure and bioactivity of SchistoFLRFamide, a FMRFamide-like neuropeptide from the locust, Schistocerca gregaria Biochem. Biophys. Res. Comm. 160(2), $850-856$.

Yamamoto D., Ishikawa S., Holman G. M., and Nachman R. J. (1988) Leucomyosuppressin, a novel insect neuropeptide inhibits evoked transmitter release at the mealworm neuromuscular junction. Neurosci. Lett. 95, 137-142. 